Goldsmiths Research Online, (C) The Author

Accepted for publication by The British J ournal of Sociology universitr of LoNDoN

The Pinochet case: cosmopolitanism and intermestic human rights

Kate Nash

Re-submitted to The British J ournal of Sociology J anuary 2007

Word length: 8200

Department of Sociology

Goldsmiths College

University of London

London SE14 6NW

+44(0)2076830157

k.nash@gold.ac.uk 
Goldsmiths Research Online. The Pinochet case

\title{
The Pinochet case: cosmopolitanism and intermestic human rights
}

\begin{abstract}
This article explores the Pinochet case, widely heralded as a landmark, as a case of 'intermestic' human rights that raises difficult normative and empirical questions concerning cosmopolitan justice. The article is a contribution to the sociology of human rights from the perspective of methodological cosmopolitanism, developing conceptual tools and methods to study how cosmopolitanising state institutions and cultural norms are inter-related. The argument is made that in order to understand issues of cosmopolitan justice, sociologists must give more consideration to political culture.
\end{abstract}

Keywords: human rights; state; justice; community; political culture. 
Goldsmiths Research Online. The Pinochet case

\section{The Pinochet case: cosmopolitanism and intermestic human rights}

Arrested in October 1998 with a warrant from a Spanish magistrate demanding his extradition for crimes against humanity committed whilst he was President of Chile following a military coup, Pinochet was put under house arrest in the UK until March 2000 when he was finally declared by the Foreign Secretary J ack Straw to be medically unfit for trial and flown home to Chile. The Pinochet case was a landmark for the human rights movement, widely celebrated as a turning point in the extension of international human rights standards (1).

The study of human rights has been dominated by legal scholarship, but in this article the Pinochet case is studied sociologically, from the perspective of cosmopolitanism (see Beck 2006a). The sociological study of human rights requires special attention to issues of justice (see Turner 2006). Although methodological and normative cosmopolitanism are distinct, the former necessarily includes the latter insofar as 'really existing' issues of cosmopolitan justice are one of the most significant sites for the cosmopolitanising of institutions and, potentially at least, for 'reflexive cosmopolitanism', or an enhanced orientation towards 'world-openness' (Beck 2006a: 6; Delanty 2006). The Pinochet case offers the opportunity to explore difficult questions for cosmopolitanism, especially concerning the 'who' of justice where borders are no longer taken-for-granted.

J ustice that is more than merely procedural requires both legitimate institutional procedures - the modern, rational procedures of law and bureaucracy - and also a bounded, concrete community that recognises those procedures as legitimate. J ustice has 
Goldsmiths Research Online. The Pinochet case

to be seen to be done - not only to those who demand it (justice can not simply be relative to demands), but to a community for whom the desire for justice in a particular case is both comprehensible and morally significant. Framing justice as 'national' in the international states system tied procedures of justice and political community together in such a way that questions of 'who' were not raised (Fraser 2006). But once this frame is disrupted, the development of cosmopolitan norms requires both the production of new formal-procedural institutions and the imagining of new political communities. How are political communities of justice formed beyond the national state, and how can sociologists conceptualise and study their formation and re-formation in relation to cosmopolitanising state institutions?

As sociologists, we cannot restrict our study of human rights to legal definitions if we are to understand emergent possibilities for cosmopolitan justice. In fact, in strictly legal terms, the Pinochet case did not concern human rights violations, which are not criminal matters; human rights law takes the form of civil and public law and offers only civil remedies. For sociological study, however, legal definitions are just part of understanding human rights. Political and popular uses of the term 'human rights' tend not to distinguish between different branches of law. For example, both Amnesty International and Human Rights Watch frequently described the Pinochet case in general terms as concerning human rights violations and in the media the case was invariably represented as concerning human rights. Human rights have meanings and effects beyond the legal domain and these are as crucial for cosmopolitan justice as changes in the law.

The Pinochet case certainly involved extremely complex legal reasoning. The initial finding by a Divisional Court that Pinochet was entitled to diplomatic immunity as a former head of state was appealed in the House of Lords where there were then three 
judgements by the Law Lords concerning the case, though only one legal decision. In the first judgement (Pinochet 1) the majority of the Lords found that Pinochet should be extradited to face criminal charges in Spain because international customary law, which would otherwise have prevented prosecution of a head of state for acts whilst committed in office, could not be understood to sanction crimes against humanity. This judgement was then set aside for reasons of alleged bias on the part of one of the judges (Pinochet 2), an unprecedented decision that could have triggered a constitutional crisis on the eve of reform of the House of Lords (Woodhouse 2003). Finally, the Lords decided that Pinochet should be extradited (Pinochet 3), on much narrower technical grounds than Pinochet 1. However, the Pinochet case also involved political maneuvering: huge public involvement (Straw received over 70,000 letters about it), vigorous lobbying of the government by NGOs, passionate political protest by Chileans in London and in Chile, more or less secret diplomatic negotiations with officials acting on behalf of other states, and a sharp re-drawing of Left-Right political lines that had, arguably, softened in the first decade after Communism. It was also a massive media event, with the Law Lords' decisions broadcast live on TV for the first time, the story of Lord Hoffman's association with Amnesty that led to Pinochet 2 breaking on Newsnight, and blanket media coverage of the story, at the beginning and at peak moments throughout the course of events. According to Geoffrey Robertson the media even played a crucial role in Pinochet's arrest: it was prompted by an article published in The Guardian on October 15'th 1998, 'A Murderer Among Us', written by Hugh O'Shaughnessy, Chairman of the Latin American Bureau (Robertson 2002: 396).

The study of human rights law operates with a strict division between international law (eg Steiner and Alston 2000), and domestic law (eg Fenwick 2002). From a sociological point of view, however, this conventional legal paradigm is misleading and it is important 
to understand how human rights are becoming 'intermestic'. Though universal in form since their inception in natural law, human rights have only come to be applied to noncitizens within and across national borders relatively recently. This does not mean, however, that borders become irrelevant in human rights cases. Human rights are becoming intermestic rather than transnational: human rights do not just cross borders, they contest, disrupt and sometimes re-configure them. 'Intermestic' marks the complexity of social processes that disrupt and re-make the 'inside' and 'outside' of states, and which are not yet definitively mapped or adequately theorised. In this respect the Univeral Declaration of Human Rights was a turning point in the globalisation of human rights, the beginning of a system that systematically monitors states' compliance in ensuring individuals' human rights, regardless of nationality. The end of the Cold War was another turning point, enabling virtual consensus on the importance of supporting civil and political human rights for individuals and groups within states and promoting the development of legal and political means to realise them (Forsythe 2000). Political use of the language of human rights is increasingly important in the rhetoric both of state elites and of NGOs (which themselves cross borders, often having ambiguous status in relation to the international/ domestic distinction) to justify action at home and abroad. Even in law, increasing legalisation of human rights complicates the international/ domestic division (3). For example, customary international law is drawn on in national courts; and national law is created through reference to international agreements and conventions, so that lawyers and judges may refer to the intentions of international actors, or to cases and law in other nations, as well as to domestic cases.

Institutions of procedural justice nevertheless all depend on the machineries of states, which sign and ratify treaties and conventions, appoint officials to serve in international institutions, enable NGOs to operate within their territories and so on. It is states that 
enable and finance legal and bureaucratic decision-making fora at the national or international level, and, in the case of international organisations, they continue to be the only systematic means by which citizens are represented, at least nominally. The continuing importance of states in terms of membership and representation of citizens as well as the historic dominance of the 'national' frame of justice means that imagining communities of justice beyond the nation must emerge from within the international system of national states. The 'international community', a term that is used ambiguously to refer to the 'community of states' or sometimes to include also intergovernmental organisations, NGOs and even ordinary citizens, must be deepened within national states if there is to be cosmopolitan justice. De-territorialised and re-territorialised political communities have to emerge through the mobilisation of identities engaged with and supportive of the extension of frames of justice to include non-national 'Others' as valid subjects of justice - and not say, charity, or benevolence of some kind - within public space formed and maintained by states.

\section{From (inter)national to cosmopolitan public policy?}

In order to study the sociological implications of the Pinochet case for cosmopolitan justice, I first developed ideal-types of public policy to explore the novelty of the case along different dimensions. The ideal-types of public policy developed here encompass both formal-procedural institutions of law-making and the administration of law, and also the cultural norms which legitimate those institutions (Considine 2005).

As an ideal-type, (inter)national public policy has been dominant at least from decolonisation until the end of the Cold War. It consists of three main elements along the overlapping dimensions of the national and the international: 
Goldsmiths Research Online. The Pinochet case

1. state sovereignty - a state is to be free from interference by other states in its policy-making and law enforcement to enable justice as self-determination of the people;

2. for self-determination to be effective, states must have sole jurisdiction over what takes place within their own national territory, where jurisdiction concerns the 'power of the state to affect people, property and circumstances' (Shaw 2003: 574);

3. public policy is made for the people who make up the nation and, ultimately, they must consent to it - if not through elections, then by not rising up against the government or the state. The frame was undoubtedly complicated after World War Two, as liberal internationalism challenged the 'internal' conception of justice on which classic sovereignty had been based, especially in the case of war crimes. However, the balance of powers until the end of the Cold War meant that international law effectively maintained classic sovereignty, being overwhelmingly concerned with keeping the peace between states in order to ensure the conditions for justice as a matter of internal politics and law (Held 2002).

Intermestic human rights cases thoroughly disrupt (inter)national public policy. In the Pinochet case, in relation to the first point above, state sovereignty was found to be illegitimate where it conflicts with international human rights norms. The principle that state sovereignty means heads of state are free to act in the state's interest and are, therefore, immune from prosecution was considered by judges in the Pinochet case and found to be unlawful, confirming the conflicting principle that only state action within human rights norms is legitimate and that individuals who act against those norms are liable for prosecution. 
Secondly, jurisdiction was problematised in the Pinochet case, as both Chilean and UK state action was circumscribed by international law. This was most evident in Chile, where the amnesty which Pinochet had been granted by a democratically elected Chilean government was not considered legitimate grounds in the UK for ignoring evidence that he had committed gross violations of human rights and could therefore be tried for crimes against humanity. Chilean legislation was held not to be relevant in the UK court. The case of the UK is more complicated, because the different Law Lords' decisions in the case have somewhat different implications, as we shall see. However, insofar as, in both cases, the UK court allowed that Pinochet should be extradited for trial in Spain under customary international law, it appeared to accept that courts have universal jurisdiction over some crimes, which should be prosecuted wherever and by whomever they have been committed. The UK therefore had a duty to extradite or to try Pinochet, regardless of considerations of 'national interest' or the embarrassment of the British government.

Thirdly, the normal frame for justice was problematised insofar as the Pinochet case raises the question of who is the public for whom the law is enacted. Pinochet was arrested in London on a warrant issued by a Spanish prosecutor acting on behalf of those tortured and murdered in Chile on Pinochet's orders, regardless of their nationality (4). The Pinochet case therefore raises in a very dramatic way the question, what are the bounds of the community for whom justice must be seen to be done in this case? And more generally, how are communities of justice to be conceived of and formed in relation to intermestic human rights, which break the bounds of assumed national political communities? 
Goldsmiths Research Online. The Pinochet case

(Inter)national public policy has been widely challenged by many aspects of bordercrossing social action associated with globalisation, which both produce new kinds of policy problems, and also networks, organizations and institutions of global governance that are growing up to deal with them. Developed out of the work of cosmopolitan sociologists and political theorists (5), the following ideal-type of cosmopolitan public policy provides a useful comparison with that of (inter)national public policy:

1. state sovereignty is increasingly being shared in international institutions of cooperative global governance, and this is necessary to meet the policy problems increasingly thrown up by globalisation (Held 1995; Slaughter 2005; Beck 2006);

2. the legitimacy of policy actors depends upon the extent to which they conform to norms of international human rights and humanitarian law developed through international state co-operation (Crawford and Marks 1998; Beetham 2000; Held 2002);

3. the legitimacy of policy depends on the appropriateness of the scale at which it is made - local, regional, national, transnational, supranational and so on - which in turn depends on the scale of the relevant policy problem and accountability to different communities according to an 'all affected' rule (Held 1995; Gould 2004; Fraser 2005).

The Pinochet case conforms very well to this model of cosmopolitan public policy in relation to the first two points. In relation to the first point, the international law under which Pinochet was prosecuted involved sharing state sovereignty. The Law Lords found that Pinochet could be extradited to Spain in accordance with customary international law - which is defined as established state practice, in accordance with international law, and followed 'from a sense of legal obligation' (Steiner and Alston 2000: 70). In addition, the 
UK law under which it was ultimately decided that he should be extradited to Spain was first developed as the Convention Against Torture in the UN, and incorporated into UK law in the Criminal J ustice Act of 1998. In relation to the second point, the way in which Pinochet repressed opposition to his military rule was found not to be acceptable because of developing customary international law against genocide and torture. Pinochet's position as a former head of state did not legitimate his actions because it conflicted with this body of developing law.

Concerning the third point, the formation of a relevant political community of justice, however, the implications of the Pinochet case are not so clear. As it is currently developing, global governance 'borrows' state coercion in order to police and enforce international norms (see Slaughter 2005). Global governance does not exist above state institutions, but through them. The claim that 'all affected' are to be included as equals in a political community aimed at realizing justice has been much more thoroughly debated in normative political theory than by sociologists and empirical political theorists (see, for example, Shapiro and Hacker-Cordon 1999), and how this might work in practice has been little considered. How are political communities of justice actually formed in practice in cases of intermestic human rights like the Pinochet case?

\section{Towards cosmopolitan public policy?}

As well as extending the institutional innovations of the cosmopolitanising state, did the Pinochet case also involve contestation of the taken-for-granted national political community of (inter)national public policy? What cultural resources were available in the case for the construction of alternative political communities accountable at different scales for justice to 'all affected’? To explore these questions, I compared constructions of intermestic human rights produced by four principal actors in the case. At issue here 
Goldsmiths Research Online. The Pinochet case

were cultural norms produced for the public, rather than technical reasoning produced in legal and bureaucratic institutions.

International non-governmental organizations (INGOs).

INGOs put pressure on states through international institutions and from within the domestic arena to fulfil international human rights obligations at home (Keck and Sikkink 1998; Risse et al 1999; Soysal 1994). In the Pinochet case, Amnesty International (AI) and Human Rights Watch (HRW) were especially prominent, granted leave to intervene in the appeal, they made written submissions to the court and were represented by counsel. They were also active, along with other INGOs, in lobbying government, and in publicizing their view of the case, producing regular reports, press releases, and public statements.

Thejudiciary

Whilst the sociology of human rights requires a wider perspective than that of legal, or even socio-legal studies, legal reasoning is obviously very important to public constructions of intermestic human rights. Here my analysis concerns the Law Lords' highly publicised judgements in Regina v. Bow Street Magistrate, ex parte Pinochet Ugarte.

\section{Politicians}

Influential politicians of the cosmopolitanising state are clearly also important to intermestic human rights cases, especially where, as in the Pinochet case, they involve direct relations with other states. In fact, ultimately the decision to extradite Pinochet lay with the Foreign Secretary in the UK government. However, since J ack Straw's decision 
Goldsmiths Research Online. The Pinochet case

was officially 'quasi-judicial', there was a formal ban on speeches and comments on the case amongst members of the government. Those few comments that were made on the case were the topic of enormous amounts of media conjecture and speculation. Widely discussed were those of Peter Mandelson, Trade Secretary, shortly after his arrest, that it would be 'gut-wrenching' to see such a 'brutal dictator' like Pinochet escape justice immediately declared 'emotional and unhelpful’ by ‘cabinet sources' but widely suspected to have been made strategically; and Tony Blair's mention of Tory support for Pinochet in a speech to the Labour Party Conference in 1999 (see

news.bbc.co.uk/ 1/ hi/uk_politics/460009.stm). Margaret Thatcher's speech to the Conservative Party Conference in 2000, which railed against her own party for abandoning him, produced a storm of media commentary (see www.guardian.co.uk/ tory99/Story/ 0,,202256,00.html).

The media

It is very difficult to know what role the media may play directly in putting pressure on politicians and judges - though the media strategies of INGOs suggest they certainly think it is important. From the point of view of the creation of political community, however, the media is clearly vital - not least because popular media itself constructs and consolidates the national framing of politics (Billig 1995; Anderson 1983). Media coverage of the case was here represented by coverage of the case from Pinochet's arrest to his departure in a selection of broadsheet and tabloid newspapers: The Guardian, The Observer, The Mirror, The Mirror on Sunday were selected as progressive, and The Daily Telegraph, The Sunday Telegraph, The Sun and The News of the World as conservative papers. 
My analysis of the material produced by these actors throughout the case was designed to get as close as possible to the meanings of intermestic human rights constructed by the actors involved whilst at the same time enabling comparison with the ideal-types of (inter)national and cosmopolitan public policy. I first coded the material into generally relevant categories (eg leadership', 'authority', law') and then recoded it in relation to the ideal-types of (inter)national and cosmopolitan public policy outlined above. The resulting models of 'global citizenship', 'cosmopolitan nationalism' and '(inter)nationalism', which I have developed and named out of this material, are simplified popular descriptions which are at the same time evaluations of the world, delineating the roles of states and of peoples, adopting positive or negative orientations towards cosmopolitanisation as exemplified by the Pinochet case. My concern here is not with how effective any of these models were in actually creating real, felt, political communities with commitments to justice for 'all affected', but rather with how meanings of intermestic human rights were produced and organized in the Pinochet case.

\section{Global citizenship}

The main public policy actors who consistently articulated and at the same time positioned themselves as advocates within the model of global citizenship, unsurprisingly, were human rights INGOs. Publicity surrounding the majority reasoning of the Law Lords in Pinochet 1 , including the Lords' televised summing up of the decision, also contributed to the construction of global citizenship, imagining a political community for justice which orients itself towards belonging with others in the world as human beings beyond the sharing of a political space created around a national state. The other actors who constructed this vision - though not as forcefully or exclusively as INGOs - were the progressive newspapers, especially the broadsheets. Global citizenship was the dominant model of the liberal press, 
Goldsmiths Research Online. The Pinochet case

especially represented in editorials and in articles, letters and appeals on the part of INGO activists and sympathizers (6).

Global citizenship had much in common with the ideal-type of cosmopolitan public policy. Indeed, and controversially, it articulated an understanding of international law as already existing in fact as cosmopolitan law, positing the following set of conditions:

1. the subjects of international law are individuals and groups, not institutions state sovereignty is irrelevant;

2. the legitimacy of policy actors depends upon the extent to which they are willing to uphold international law - law (as fact) is equivalent to justice (as norm);

3. the community for whom justice is to be done is citizens of the globe who are constituted as such by international law.

Advocates of global citizenship acted as if the state were a neutral political and legal apparatus - a carrier for global values of international law. The strategy of INGOs here was one of what we can call 'performative declaration'. The rhetoric produced by AI and others sought to represent their 'clients' (those who had been tortured and the relatives of the disappeared) in legal terms, as if cosmopolitan law defending individual entitlements regardless of national boundaries already existed quite uncontroversially (see Held 2002; Hirsh 2003). For example, in a report immediately following the Divisional Court's decision (before the case went to appeal), that Pinochet did have diplomatic immunity from prosecution, AI stated that The UK cannot refuse to implement the rule of international law' in extraditing Pinochet to Spain for trial ('The inescapable obligation of the international community to bring to justice those responsible for crimes against humanity committed during the military government in Chile' 22/ 10/98) (my italics)). 
Global citizenship gained a good deal of credibility with the Law Lords' decision in Pinochet 1. The judgement articulated a model of global citizenship insofar as it held that state sovereignty does not trump the legal entitlement of individuals, regardless of their nationality or residence, thus constituting all individuals as global citizens in international law. However, the Law Lords' interpretation of customary international law came as a surprise to international lawyers, even if they hoped for this outcome (Bianchi 1999; Sands 2005). Pinochet 1 was decided by a majority of just three to two and justifications for majority and dissenting opinions turned to a large extent on different interpretations of international law, with dissenting Lords taking the traditional view that it is solely to regulate relations between sovereign states so that former Heads of State are immune from prosecution, even in the case of crimes against humanity. The Lords staged a clash between fundamental principles of international lawitself and Pinochet 1 was a landmark decision because it might easily have gone the other way.

In the model of global citizenship, the political community of global citizens is also constituted as 'always already' existing as a consequence of international law - though it is, in fact, contentious and, at best, in development. Advocacy for global citizenship on the part of INGOs and progressive journalists is presumably intended to put pressure on judges and politicians and in this respect it successfully challenges the hegemonic (inter)national frame of justice: Pinochet should be extradited to Spain or tried in the UK, because international law is clear. On the other hand, however, the model of global citizens as 'always already' constituted by the 'fact' of international law offers no resources for debate over the scales at which legitimate political communities beyond the national state are to be formed, and for whom. Framing the relevant political community as 'all humanity', the model of global citizenship provides neither resources for thinking through 
the problem of scale, nor of how 'all affected' in this case might be delimited. The difference between justice that is merely procedural and justice that is recognized as significant and legitimate by a concrete group of people is elided in a construction of international law as positivist that is neither historically realistic, nor normatively justified. J ustice, and especially 'cosmopolitan justice', is never merely procedural - who is brought to trial, by whom and for what does not solely depend on legal procedures but also on political will and state capacities. (In fact, Pinochet was welcomed into Britain by the UK government and only arrested because of the determination of a Spanish prosecutor, though he should, according to the Law Lords' decision, have been arrested automatically and tried by the UK authorities.) The model of global citizenship, in its celebration of law as always already cosmopolitan, closes off any questions about who is the political community for whom such trials are carried out, who decides who should be tried, when and where.

\section{Cosmopolitan nationalism}

The model of cosmopolitan nationalism is a hybrid, articulating something like a cross between (inter)national and cosmopolitan public policy. This is a model that posits cosmopolitan public policy as progressive, as the best possible future for global society. However, at the same time, and paradoxically, it constructs 'we' the people as rooted strongly in nationalist sentiment and passionate loyalty to a civic nation. In relation to the Pinochet case, cosmopolitan nationalism was most evident in the coverage of the progressive tabloid press. Examples throughout the case include: You can stick your justice; arrogant Pinochet insults Britain' (The Daily Mirror 12/ 12/ 98); 'British justice can still shine like a beacon across the world', the opening line of an editorial headlined No escape from justice for tyrant' (The Daily Mirror 26/ 11/98); and, when Straw announced Pinochet was unfit for trial, from a letter under the headline 'Day of shame', It is a sad 
Goldsmiths Research Online. The Pinochet case

day for Britain and for justice' (The Daily Mirror 3/3/00). Patriotism was more muted in the progressive broadsheets, overt only in letters. For example, '[Pinochet's arrest] gives me hope that Britain can regain its reputation as a leading force for democracy and human rights' (The Guardian 19/10/98); 'Britain can take the lead in providing a clear global signal to those who commit genocide and human rights abuses' (The Guardian 24/ 10/98); and, when Pinochet was about to be released, 'For the first time in my life...I am ashamed of being British', The Observer 12/3/00. (7)

Cosmopolitan nationalism has been very popular among politicians in the UK government in the last fewyears. Tony Blair's government has tended to present itself as advancing cosmopolitan public policy, but it can only do so whilst appealing to an electorate that is, as a matter of fact, organized on a national basis (see Nash forthcoming). In the Pinochet case, cosmopolitan nationalism is hinted at in Tony Blair's speech to the Labour Party in 1999, which created an equivalence between fox hunting, Pinochet and hereditary peers in order to portray Labour as liberating 'British strength and confidence' from the 'forces of conservatism' for a progressive politics to take on the 'forces of change driving the future' that 'Don't stop at national boundaries. Don't respect tradition.... [W]ait for no-one and no nation...[A]re universal.'

Cosmopolitan nationalism articulates the following points in comparison with (inter)national public policy:

1. the subjects of international law are individuals and groups who are members of nations;

2. the legitimacy of policy actors depends upon the extent to which they are willing to uphold international law - law is equivalent to justice; 
Goldsmiths Research Online. The Pinochet case

3. the community for whom justice is to be done is made up of individuals who identify as members of nations represented by national states

The basic motif of this model is that 'we' - who are unquestionably members of a national political community first and foremost - take pride in our state insofar as it upholds universal human rights that are applicable across the world. Again facts and norms are intertwined in this model. As a matter of fact, cosmopolitan nationalism presupposes that we are in a kind of transitional phase, between the international states system and a more cosmopolitan version of law as breaking through state sovereignty; especially where gross violations of human rights have occurred or in order to prevent them, states are no longer self-contained discrete units of jurisdiction. However, descriptive and evaluative analysis overlap insofar as politics is seen as misplaced in cases of gross violations of human rights, as a brake on justice rather than as a legitimate domain of public policy decisionmaking. Gross violations of human rights both will be and should be a matter for international law rather than for politics, whether national or international.

Cosmopolitan nationalism was confirmed in the legal reasoning of Pinochet 3 - albeit in such complicated ways as to be virtually unintelligible to non-lawyers. Pinochet 3 was far less dramatic and novel than Pinochet 1, though equally highly publicised. The Law Lords granted extradition on narrow technical grounds and reduced the number of alleged crimes on the basis of 'double criminality' (a principle not discussed in the previous hearing) in the Extradition Act, allowing only those charges of crimes to stand which were committed after the date at which the Torture Convention was incorporated into English law. In this respect the decision was at odds with judges' interpretation in Pinochet 1 that some acts, including torture and hostage-taking, are crimes in international law, wherever and whenever they are committed. The reasoning of Pinochet 
Goldsmiths Research Online. The Pinochet case

3 constructed, then, a much more equivocal endorsement of international customary law, and the enactment of 'quasi-universal' rather than universal jurisdiction, according to which obligations are only accepted by a state on the basis of international treaties insofar as they have become part of domestic law by ratification or incorporation (Shaw 2003: 598). The Lords at the same time confirmed the status of international law as piercing (Chilean) sovereignty in not allowing Pinochet immunity from prosecution for alleged international crimes, whilst at the same time minimising its impact on traditional understandings of international law by confirming (UK) sovereignty in allowing only obligations of international law that had been incorporated as domestic law to count as law.

Pinochet 3 is very unclear, in terms of legal precedent and also in terms of popular understanding, with both those for and those against putting Pinochet on trial claiming victory. It does, however, make sense from within the paradoxical model of cosmopolitan nationalism.

The basic orientation of cosmopolitan nationalism is imperialist in that it is assumed that only some nations are able to uphold international law, and they must take responsibility for those that are not capable. Interestingly the inferiority of other nations was most overt in relation to other European powers rather than Chile. It was especially evident when Belgium, France and Switzerland made a bid, with AI, to use the International Court of J ustice in the Hague to stop Straw releasing Pinochet to return to Chile on grounds of ill-health. For example, beginning a satirical article with 'Appearance: Short, squat, dull country, filled with people eating too many chips and not being able to make up their minds which language to speak', The Guardian went on to list recent Belgian violations of human rights including 'torture and unlawful killing' in Somalia, 'slave 
Goldsmiths Research Online. The Pinochet case

trafficking', deaths in police custody and 'one of the biggest child porn stories in Europe, mixed in with police corruption and bungling' suggesting that such a history ruled Belgium out as a state that could be trusted to administer international justice (The Guardian 27/ 1/2000). This is, of course, deeply ironic given the British disinclination, across progressives and conservatives, to reflect on our own imperialist history (Gilroy 2004).

In cosmopolitan nationalism the hegemonic 'who' of the political community for whom justice is necessary is challenged and expanded beyond the nation insofar as nonnationals are the legitimate objects - though not subjects - of justice. In this respect, cosmopolitan nationalism challenges hegemonic (inter)national public policy. In other respects, however, cosmopolitan nationalism confirms the nation as the political community most relevant to justice-claims insofar as it is assumed that procedures of justice are in safe hands only so long as 'we nationals' are administering it. 'All affected' are not necessarily members of a political community made up of active subjects once claims for justice are extended beyond the nation. They are rather the passive recipients of justice that is endorsed by a (superior) national political community capable of responsibly deciding whether there is a case for justice to be answered, who is entitled to it, and how it is to be administered.

\section{(Inter)nationalism}

The model of (inter)national public policy, whilst challenged by the Pinochet case in some ways, was reconfirmed in others. This model was exemplified in Thatcher's dramatic speech to the Conservative Party, which re-iterated themes widely covered by the conservative media throughout the case. It was also represented, in a much more muted fashion, in the progressive broadsheets. For example, from the beginning of the case 
Goldsmiths Research Online. The Pinochet case

writers at The Guardian were critical of the British authorities for allowing Pinochet to enter the country (while he was not given leave to enter France), a criticism that assumes proper diplomatic relations between states are more important than the universal justice of international norms (8).

The emotional and moral economy of the Pinochet case is completely different in the model of (inter)nationalism: 'our' obligations as a nation are to foster 'national interests' rather than to consolidate and uphold universal principles of international human rights regardless of state sovereignty, especially wise management of tax-payers' money and good commercial relationships with other countries, as well as showing loyalty and respect to our friends and care for our reputation as a state in the international society of states. In (inter)nationalism, only national states have jurisdiction over acts committed within their national territories, and international law is nothing more than real politick masquerading as law, which potentially leads to greater injustice for everyone. In terms of political community, while each national state is a discrete individual entity, for (inter)nationalism, the lives of 'our' national fellows are worth far more to 'us' than others. This was made explicit in one of Thatcher's arguments, rehearsed from the beginning of the case in the conservative press, that Pinochet was entitled to respect and honour because he had been of invaluable help during the Falklands war, saving many British lives as a result.

However, what is most interesting from the point of view of our discussion here is that it is only from within the terms of the model of (inter)nationalism that a strongly antiimperialist perspective emerged with respect to the Pinochet case. In the conservative press, anti-imperialism was based on unconditional principles of national selfdetermination and tended to slip into relativism. Pinochet's brutality - and the 
conservative press did not dispute that Pinochet was responsible for torture and the disappearance of about 3 - 4,000 people - was justified by circumstances; above all, by the need to combat communism. There are many examples of this approach in The Daily Mail, including an article by Norman Tebbit, former Cabinet Minister in Thatcher's government: The Chileans believe that they have to forget the methods Pinochet used to deliver them from communism and give them prosperity and democracy' in 'Make them hit the road J ack' 25/ 10/ 1998. A letter from Thatcher to The Times on October 21st 1998 which stated that there were 'acts of violence' on both sides was widely quoted; and the argument that Pinochet freed Chile also featured in her speech to the Conservative Party conference: There are implications for Chile, where the small minority of communists who once nearly wrecked the country under Allende will now be encouraged to overturn the prosperous, democratic order that Pinochet and his successors built.' (9) From this point of view, because national concerns are (naturally) dominant for national political communities and states, political judgements that may seem wrong to one people must be understood as appropriate in another national context.

In the progressive papers, anti-imperialist criticisms were much more conditional. In its progressive form (inter)nationalism in the Pinochet case constructed state sovereignty as viable only insofar as it enabled democracy and respect for human rights. There was, therefore, consideration of how Chile had consolidated itself as a democratic state as a result of the actions of international elites in the Pinochet case to the point where Pinochet might even stand trial in Chile should he be returned. Several reports from Santiago that appeared in The Guardian towards the end of the case, for example, suggest that changes had been produced by Pinochet's arrest to make Chile freer and more democratic (eg 'People find the confidence to face the truth but fear the general's last laugh' 16/10/99, and 'Chilean calls grow for Pinochet trial' 6/3/00). 
Goldsmiths Research Online. The Pinochet case

The implicit principle here is that foreign policy - the decisions of one state (UK), in voluntary co-operation with others, should contribute to establishing democracy and the rule of law in another (Chile) - but as a matter of ethical foreign policy, in which international law might figure strategically, but does not direct state conduct (10).

Clearly the (inter)nationalist model does not contest (inter)nationalist public policy at all, but rather supports it. As such, although it does enable questions of imperialism to be raised, it provides no resources for thinking about dilemmas of cosmopolitan justice and how political communities for justice might be formed beyond national states.

\section{Conclusion}

In this article I have considered the Pinochet case as a much-celebrated example of the realisation of international human rights norms and as potentially therefore offering the resources for a transition to cosmopolitan justice. Developing ideal-types of (inter)national and cosmopolitan public policy I have argued that institutionally the Pinochet case was undoubtedly innovative. However, its value is much less clear if we consider that justice also requires community.

One methodological implication of this study of the Pinochet case is that cosmopolitan sociologists and empirical political theorists must take political culture much more seriously. Cosmopolitan theorists have neglected both the theorisation and the detailed empirical examination of political culture and this neglect makes it impossible to understand political community as shared meanings and constructed identity in relation to institutions of authoritative governance. It is not sufficient to point out, as cosmopolitan theorists tend to, that imagining political community as represented by the national state is comparatively recent historically, and that it is not immutable (Held and 
Goldsmiths Research Online. The Pinochet case

McGrew 2002). Nor is it enough to consider influences in global culture on reforming national communities as a result of the growth of global communications and transnational communities, without reference to institutional changes (see Fraser forthcoming). As Benhabib has argued, fostering 'ethical cosmopolitanism' involves the iteration of democratic norms (Benhabib 2004). Sociologists of cosmopolitanism can not be satisfied, however, with assuming that the cosmopolitanisation of institutions in broadly multicultural or even post-national societies is matched in a general way by the cosmopolitanisation of identities, especially in relation to law and politics. What is needed are concrete, empirical studies of how iterations of cultural norms in relation to institutional changes lead to dis-identifications and the formation of newidentities, or to the modification or the reactive consolidation of established identities, and what relation they bear to a cosmopolitan ideal of justice. As we have seen in the Pinochet case, intermestic human rights now require re-imagining communities of justice, not only for normative or abstract theoretical reasons, but as a necessity that is thrown up by the development of the institutions of the cosmopolitanising state. 
Goldsmiths Research Online. The Pinochet case

\section{Acknowledgements}

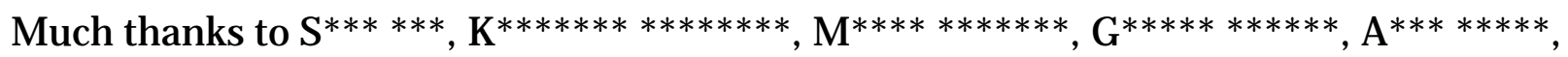
$\mathrm{F} * * * * * * * * * * *$ and $\mathrm{N} * * * * * * * * * * * * * *$ for all their help and encouragement with this article.

\section{Notes}

1. See Sands 2005 on Pinochet as a landmark, legally but also because of the way it made 'international law' a topic of public discussion to an unprecedented degree. Cosmopolitan sociologists have taken the Pinochet case as an indication that we may be on the threshold of a new era of cosmopolitan law (Habermas 1999; see also Beck 2006: 223).

2. This situation is now becoming more complex - especially when it is a matter of prosecuting crimes against humanity that took place in peace time rather than in armed conflict (for example, in cases brought to US courts under the Alien Tort Claims Act private individuals may be brought to trial for gross violations of human rights; see Meckled Garcia and Cali 2006: 16).

3. The legalisation of human rights involves the way in which, since the end of the Cold War, international agreements are becoming more detailed, precise and binding; and law that draws on and invokes human rights is increasingly interpreted and applied in national and international courts (Abbott, Keohane et al. 2001).

4. Whilst the first warrant for Pinochet's arrest referred only to Spanish victims, this was found to be bad in law' and a second was issued that did not refer to victims according to nationality. 
5. Key texts in the development of cosmopolitan sociology (as distinct from philosophy) include Archibugi et al. 1998; Archibugi 2004; Beck 2002, 2003, 2006a, 2006b;

Benhabib 2004; Delanty 2006; Held 1995, 2002; Habermas 1999, 2001; Fraser 2005, 2006, and forthcoming; Turner 2002; Woodiwiss 2002.

6. Examples from the very beginning of the case, which set the tone for subsequent coverage, include: H. O’Shaughnessy, 'A murderer among us' The Guardian 15/ 10/ 98; J . Hooper 'The game is up for Pinochet' The Observer 18/ 10/98, and an (untitled) editorial in the same edition; B. Wazir's interview with Carlos Reyes (leader of Chile Democratico) in The Guardian 19/ 10/98; all letters to The Guardian 19/ 10/ 98; The Mirror's editorial 'Evil Pinochet must now face justice' 19/10/98; and letters in The Mirror under the headline 'The right and human rights' 23/10/98. The progressive papers represented this model strongly throughout the case. Examples from the end of the case include: The Mirror 'Betrayed; torture victims round on J ack Straw after he allows Chilean tyrant Pinochet to fly home', and 'MP Anne slams Pinochet victory' both 3/3/00 when Straw announced Pinochet was unfit for trial; also The Observer M. Lattimer (AI Director of Communications) 'Only tough judicial action can halt the torturer's roll call of abuse' 24/ 10/99; and an interview with Claudio Cordone, the leader of AI's Pinochet campaign in The Guardian 4/3/00.

7. Cosmopolitan nationalism was not possible in this case for the conservative press because of the polarisation of Left and Right over Pinochet. In other cases, however, it is possible that the distribution of these models could be quite different across conservative and progressive media. 
8. For example, H. Young ‘A wicked man’s arrest squeezes old principles out of New Labour' 22/ 10/98; and a letter under the headline 'It's safe to come out Adolf' which ended Whereas the right of the British legal system to put a former head of state on trial may be in question, that of Her Majesty's Government to refuse admission to undesirable aliens is not' $30 / 10 / 98$. The Guardian also ran occasional reports and commentary that fit more easily into the model of (inter)nationalism than that of global citizenship: for example, a report from legal and political correspondents, 'Straw Hints at Deal with Chile over Pinochet' 23/ 10/98, and a letter protesting 'foreign interference in the affairs of Chile' and ending with We are not a Spanish colony and will never be a British one. A basic human right is free determination. Let us exercise this right' 5/ 11/98.

9. Anti-colonialism was a recurrent theme of conservative tabloid opinion pieces and editorials. For example, from The Daily Mail, P. J ohnson Left-wing J udges and a Shabby Omission' 9/ 12/98 on the alleged bias of Lord Hoffman; J ack's all right... what about Chile?' 10/ 12/98 and 'Tories and Chileans Pile the Pressure on Straw in Extradition Row' 27/ 11/98; from The Sun, an editorial 'Why Has Britain Arrested a Friend in Need?' 19/ 10/98, and a report from G. Pascoe-Watson, 'Pinochet in Tears as He Faces Trial' 10/ 12/98. The Daily Telegraph generally gave what appeared to be a more comprehensive and balanced account of the case, but it did orient stories towards unrest in Chile as a result of Pinochet's arrest, with headlines like 'Tension Turns to Violence on the Streets of Santiago' 22/ 10/ 98 and 'Pinochet's Return Puts Democracy Under Strain' 5/ 3/ 00.

10. The first Labour government under Tony Blair was officially associated with 'ethical foreign policy', an idea that Robin Cook, the Foreign Secretary put forward soon after it was elected. 
Goldsmiths Research Online. The Pinochet case

\section{References}

Anderson, B. (1983). Imagined Communities: Reflections on the Origin and Spread of

Nationalism. London: Verso.

Billig, M. (1995). Banal Nationalism London: Sage.

Abbott, K. W., R. O. Keohane, et al. (2001). The Concept of Legalization.

Legalization and World Politics. Cambridge, Massachusetts, MIT Press.

Archibugi D, Held, D. and Kohler, M. (1998) Re-Imagining Political

Community: Studies in Cosmopolitan Democracy. Stanford, California:

Stanford University Press.

Archibugi, D. (2004) “Cosmopolitan Democracy and its Critics: A Review”

European J ournal of International Relations 10(3).

Beck, U. (2002) "The Cosmopolitan Perspective: Sociology in the Second Age of Modernity" in S. Vertovec and R. Cohen (eds) Conceiving

Cosmopolitanism: Theory, Context, and Practice Oxford, Oxford University

Press.

Beck, U. (2003) "Toward a New Critical Theory with a Cosmopolitan Intent"

Constellations 10(4)

Beck, U. (2006a). "Unpacking cosmopolitanism for the social sciences: a research agenda." British J ournal of Sociology 57(1).

Beck, U. (2006b). Power in the Global Age. Cambridge, Polity.

Beetham, D. (2000). Democracy and Human Rights. Cambridge, Polity Press.

Benhabib, S. (2004). The Rights of Others: Aliens, Residents and Citizens.

Cambridge, Cambridge University Press.

Bianchi, A. (1999). "Immunity versus Human Rights: The Pinochet Case."

European J ournal of International Law 10(2): 237-277.

Considine, M. (2005). Making Public Policy. Cambridge, Polity. 
Goldsmiths Research Online. The Pinochet case

Crawford, J . and S. Marks (1998). The Global Democracy Deficit: an Essay in International Law and its Limits. Re-imagining Political Community: Studies in Cosmopolitan Democracy. Stanford, California, Stanford University Press.

Delanty, G. (2006). "The cosmopolitan imagination: critical cosmopolitanism and social theory." British Journal of Sociology 57(1).

Fenwick, H. (2002) Civil Liberties and Human Rights. London, Cavendish Publishing Ltd. 3rd edition

Fraser, N. (2005). "Reframing J ustice in a Globalizing World." New Left Review 36.

Fraser, N. (2006). "Abnormal J ustice." Critical Inquiry 32(3).

Fraser, N forthcoming “Transnationalizing the Public Sphere: On the Legitimacy and Efficacy of Public Opinion in a Postwestphalian World.” Theory, Culture and Society

Forsythe, D. (2000) “Human Rights in International Relations” Cambridge, Cambridge University Press.

Gilroy, P. (2004) After Empire: Melancholia or Convivial Culture London, Routledge.

Habermas, J . (1999). “Bestiality and Humanity: a War on the Border between Legality and Morality." Constellations. 6(3)

Habermas, J . (2001). The Postnational Constellation: Political Essays. Cambridge, Polity.

Held, D. (1995). Democracy and the Global Order: from the Modern State to Cosmopolitan Governance. Cambridge, Polity Press.

Held, D. (2002). "Law of States, Law of Peoples: Three Models of Sovereignty." Legal Theory 8(1): 1-44. 
Goldsmiths Research Online. The Pinochet case

Held, D. and A. McGrew (2002). Globalization/Anti-Globalization.

Cambridge, Polity.

Hirsh, D. (2003). Law Against Genocide: Cosmopolitan Trials. London,

Glasshouse Press.

Keck, M. and Sikkink, K. (1998). Activists beyond Borders: Advocacy

Networks in International Politics Ithaca, New York, Cornell University Press.

Meckled-Garcia, S. and Cali, B. (2006). The Legalization of Human Rights:

multidisciplinary perspectives on human rights and human rights law

Routledge, London.

Nash, K. 'Global citizenship as showbusiness: the cultural politics of Make

Poverty History’ Media, Culture and Society forthcoming

Risse, T, Ropp, S. and Sikkink, K. (1999) The Power of Human Rights:

Institutional Norms and Domestic Change Cambridge, Cambridge University

Press.

Robertson, G. (2002). Crimes Against Humanity: the Struggle for Global

J ustice London: Penguin. 2nd edition.

Sands, P. (2005). Lawless World: America and the Making and Breaking of

Global Rules. London, Allen Lane.

Shapiro, I. and C. Hacker-Cordon, Eds. (1999). Democracy's Edges.

Cambridge, Cambridge University Press.

Shaw, M. (2003). International Law. Cambridge, Cambridge University Press.

Slaughter, A.-M. (2005). A New World Order. Princeton, Princeton University

Press.

Soysal, Y. (1994). Limits of Citizenship: Migrants and Postnational

Membership in Europe. Chicago, University of Chicago 
Goldsmiths Research Online. The Pinochet case

Steiner, H. and P. Alston, Eds. (2000). International Human Rights in

Context: Law, Politics, Morals. Oxford, Oxford University Press. $2^{\text {nd }}$ edition.

Turner, B. (2002) “Cosmopolitan virtue, globalization and patriotism” Theory,

Culture and Society 19(1-2)

Turner, B. (2006) Vulnerability and Human Rights Pennsylvania,

Pennsylvania State University Press

Woodiwiss, A. (2002). "Human Rights and the Challenge of

Cosmopolitanism" Theory, Culture and Society 19(1-2) 